\title{
Effect of hydrocooling, packaging, and cold storage on the post-harvest quality of peppermint (Mentha piperita L.)
}

BARBOSA, C.K.R. ${ }^{1 *}$; FONSECA, M.C.M.2; SILVA, T.P. ${ }^{3 ;}$ FINGER, F.L.1; CASALI, V.W.D.1; CECON, P.R. ${ }^{1}$ Universidade Federal de Viçosa. Avenida P.H. Rolfs s/n. Viçosa, MG, Brazil. CEP 36570-900. ${ }^{2}$ Empresa de Pesquisa Agropecuária de Minas Gerais. Avenida P.H. Rolfs s/n. Viçosa, MG, Brazil. CEP 36570-900. 3Universidade Federal dos Vales do Jequitinhonha e Mucuri. Avenida Vereador João Narciso, 1380. Unaí, MG, Brazil. CEP 38610-000. *Autor para correspondência: camilakarenr@gmail.com

\begin{abstract}
The purpose of this study was to assess the effects of hydrocooling and polyethylene terephthalate (PET) perforated and non-perforated packaging on post-harvest quality of peppermint (Mentha piperita L.) leaves stored at 5 and $25^{\circ} \mathrm{C}$. The experiments were conducted using a subdivided parcel layout in a completely randomized design with four replicates. Each parcel used a 2x3 layout (two hydrocooling treatments and three packaging treatments) with subparcels for storage time. The shelf life, chlorophyll content, mass loss (ML), relative water content (RWC), total soluble sugars (TSS), reducing sugars (Red), non-reducing sugars (NRed) and starch of the leaves were determined. Cold storage increased the shelf life of the peppermint by up to 64 times (>15 days). Hydrocooling increased the RWC of the leaves. Plastic packaging was effective in maintaining the RWC. Unperforated packages more effectively prevented $M L$ in the peppermint leaves and prevented the leaves from wilting for a longer period of time. The chlorophyll content of the leaves varied according to the treatment. The soluble sugars and starch levels varied according to RWC. Hydrocooling with the use of non-perforated plastic packages was the most effective method for maintaining the postharvest quality of the peppermint.
\end{abstract}

Keywords: Medicinal plants, shelf life.

RESUMO: Efeito do hidroresfriamento e embalagem sobre hortelã-pimenta fresca armazenada em temperatura ambiente e ambiente refrigerado. $O$ trabalho objetivou avaliar os efeitos do hidroresfriamento e da embalagem de politereftalato de etileno (PET) perfurada e não perfurada na qualidade pós-colheita de folhas de hortelã pimenta (Mentha piperita L.) armazenadas em temperatura ambiente e sob refrigeração. Os experimentos foram instalados seguindo o esquema de parcela subdividida, tendo na parcela o esquema fatorial $2 \times 2$ (dois tratamentos envolvendo hidroresfriamento e dois tratamentos envolvendo embalagens) e nas subparcelas os tempos de armazenamento no delineamento inteiramente casualizado com quatro repetições. Foi determinada a vida de prateleira, os teores de clorofila, a perda de massa fresca (PM), o teor relativo de água (TRA), os teores de açúcares solúveis totais (AST), redutores (RED), não redutores (NRED) e amido das folhas. $O$ armazenamento refrigerado aumentou em até 64 vezes ( $>15$ dias) a vida de prateleira de hortelã-pimenta. $O$ hidroresfriamento aumentou o TRA das folhas. A embalagem plástica foi efetiva no aumento da vida de prateleira de hortelã-pimenta sendo eficiente na manutenção dos TRA das folhas. A embalagem não perfurada foi mais eficiente na prevenção da PM. O teor de clorofila das folhas variou de acordo com o tratamento. AST, RED, NRED e amido variaram de acordo com TRA nas folhas. O hidroresfriamento juntamente com utilização de embalagem não perfurada foi o método mais eficiente na manutenção da qualidade pós-colheita de hortelã-pimenta.

Palavras-chave: Plantas medicinais, vida de prateleira.

\section{INTRODUCTION}

Mentha piperita L. belongs to the Lamiaceae (Labiatae) family. Originating in Europe and North Africa, the species is widely grown and sold in Brazil as a food, cosmetic, seasoning, and medication (Grandi, 2014).

The products are generally harvested when 
they reach the optimal conditions visually or are consumed. However, spoilage begins at the moment that they are harvested. The rate of deterioration varies according to the product and its metabolism and may be very fast. Due to the large distances that the product generally must travel between the location of production and the shelflife of the consumer, the demand for postharvest techniques to maintain the quality of the fresh product for longer periods of time has grown (Wills et al., 2007).

After harvesting and sorting, medicinal plants have three distinct destinations: sale of the fresh plants, extraction of their active components, or preservation by drying (Silva \& Casali, 2000).

Several factors affect the shelf-life of fresh plant products at the market including different varieties, cultivation, climatic factors during growth, the growth stage at harvest, and postharvest handling and conditions. Selection, cleaning, washing, trimming, sorting, measurement, peeling, curing, maturation, treatments with hormones, other agricultural inputs, and above all, packaging affect the quality of the product being sold (Wills et al., 2007).

Postharvest handling is considered a substantial problem for Brazilian agriculture. The knowledge and technology to reduce postharvest losses are lacking. Vegetables senesce very rapidly and therefore lose their attractiveness and nutritional value.

Several simple techniques allow the quality of the product to be maintained for a longer period at a reasonable cost. The goal of this study was to assess the effects of hydrocooling and pack, perfurated and unperfurated, on the postharvest quality peppermint (Mentha piperita L.) leaves stored at 5 and $25^{\circ} \mathrm{C}$.

\section{MATERIAL AND METHOD}

Two experiments were conducted to determine the best storage conditions for fresh plants: storage at room temperature $\left(22^{\circ} \mathrm{C}\right)$ and refrigeration $\left(5^{\circ} \mathrm{C}\right)$.

The experiments were conducted using a subdivided parcel layout in a completely randomized design with four replicates. Each parcel had a $2 \times 2$ layout (two hydrocooling treatments and two packaging treatments) with subparcels for storage time. Treatments consisted of either none or one of two types of packaging, with or without the use of hydrocooling prior to packaging. Thus, the treatments included the following: T1) Perforated plastic packaging, T2) Hydrocooling + perforated plastic packaging, T3) Unperforated plastic packaging, T4) Hydrocooling + unperforated plastic packaging,
T5) Hydrocooling and no packaging, and T6) No packaging or hydrocooling.

Hydrocooling was performed by immersing the leaves in $5^{\circ} \mathrm{C}$ water in a Styrofoam box for a predetermined amount of time. The leaves, packaged or unpackaged, were then stored on a lab bench for Experiment I and in a refrigerator for Experiment II.

The following parameters for postharvest quality of the plant were then analyzed: visual analysis and shelf life, loss of fresh mass in the leaves, relative water content, and chlorophyll and carbohydrate levels. The loss of fresh mass was estimated as a ratio to the initial weight of the leaves before treatment. The data were transformed into accumulated loss of fresh mass. The relative water content of the leaves was calculated as described by Catsky (1974) with the equation proposed by Weatherley (1950). The chlorophyll quantity was estimated with a portable SPAD-502 meter [Soil-Plant Analysis Development (SPAD) Section, Minolta], as it is a non-destructive process. Six points along the leaf blade of two previously marked leaves were read, and the average was expressed in SPAD units. The total soluble sugar was measured using the phenol-sulfuric acid method (Dobois et al., 1956), and reducing sugars were quantified by the Nelson-Somogyi method (Nelson, 1944). Starch was measured using the method described by McCready et al. (1950).

Data were analyzed using analysis of variance and regression. The means of the qualitative factors were compared using Tukey's test at a 5\% probability level. Quantitative factors were submitted to regression analysis, and the model chosen was based on the coefficient of determination and biological phenomenon. The SAEG 9.1 Statistical Analysis Program was used.

Due to the rapid senescence, no packed plant data, hidrocooling or not, were not included in the statistical analysis and was made only descriptive analysis. Regardless of the interaction with the greatest significance, the option to split the model was chosen due to the goals of the study.

\section{RESULTS AND DISCUSSION}

\section{Experiment 1 - Postharvest quality of fresh peppermint stored at room temperature as a function of hydrocooling and packaging}

Hydrocooling time - There was a rapid decrease in temperature in the peppermint branches as a function of the hydrocooling time up to 20 minutes after the start of the procedure (Figure 1). The temperature of the branches oscillated

Rev. Bras. Pl. Med., Campinas, v.18, n.1, supl. I, p.248-255, 2016. 


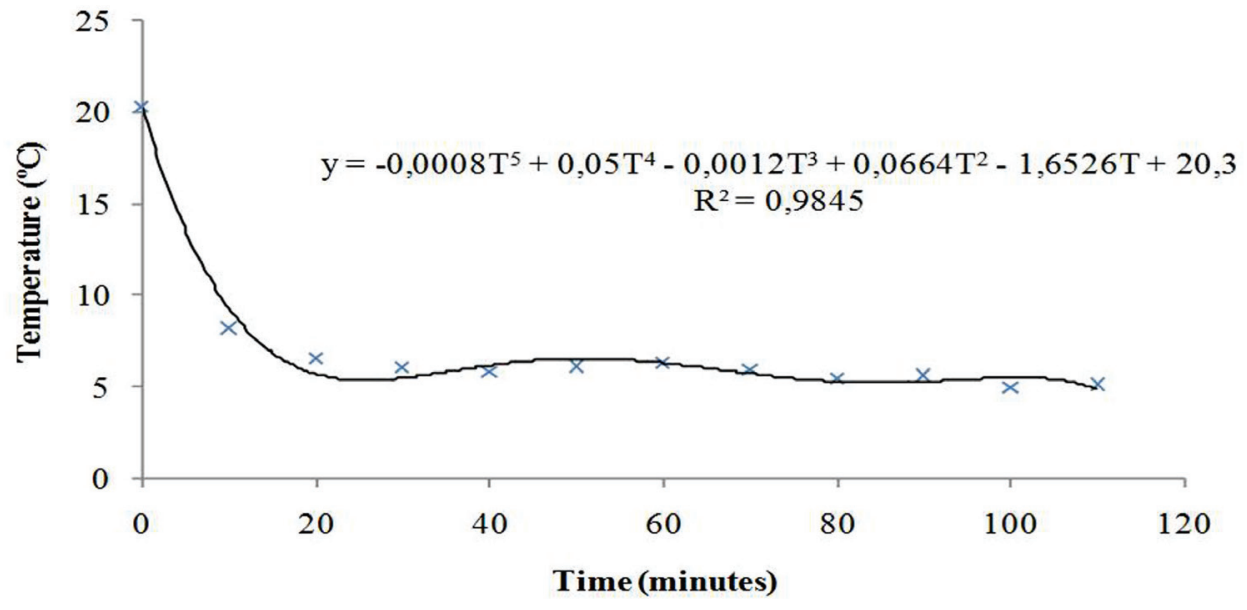

FIGURE 1. Temperature of peppermint (Mentha piperita L.) leaves during hydrocooling. Viçosa - MG, 2013.

between 6 and $7{ }^{\circ} \mathrm{C}$ for the remainder of the time until the analysis was completed at 110 minutes. During this time, the temperature of the peppermint branches decreased by $14.3^{\circ} \mathrm{C}(70.44 \%)$ at a rate of $0.71^{\circ} \mathrm{C}$ per minute.

Thus, 20 minutes of hydrocooling was determined to be ideal, after which equilibrium between the refrigerated air and the peppermint branches was achieved.

Visual Analysis and shelf life - Unpackaged plants had the shortest shelf life (Table 1).

We observed rapid water loss and, consequently, leaf wilting, a symptom that prevents the plants from being sold. Hydrocooled plants remained saleable for a longer period of time (12 hours) compared to non-hydrocooled plants (6 hours). This result was also observed in packaged plants, with or without perforation. Peppermint branches packaged in perforated packages had a shelf life of up to 168 hours when hydrocooled and 48 hours when not hydrocooled. For branches packaged in unperforated packages, the total shelf

TABLE 1. Shelflife of Mentha piperita L. leaves stored at room temperature, per treatment; No packaging (NP), packaging $(P)$, perfored packaging (PP) and hidrocooling (HC).

\begin{tabular}{ccc}
\hline Treatment & $\begin{array}{c}\text { Shelflife } \\
\text { (hours) }\end{array}$ & $\begin{array}{c}\text { Shelflife } \\
\text { (relative increase*) }\end{array}$ \\
\hline NP & 6 & \\
NP + HC & 12 & $100 \%$ \\
PP & 48 & $700 \%$ \\
PP + HC & 168 & $2700 \%$ \\
P & 120 & $1900 \%$ \\
P + HC & 168 & $2700 \%$ \\
${ }^{*}$ Compared to plants NP
\end{tabular}

life was up to 168 hours when hydrocooled and 120 hours when not hydrocooled. The relative increase in shelf-life for peppermint was twofold using hydrocooling alone, 20 fold using packaging alone, and 28 fold with hydrocooling and packaging, with or without perforation.

The hydrocooled and packaged branches had yellowing and darkening of the leaves (spoilage) at the end of storage, characteristics that determine the end of their shelf life. This result may be due to the eventual condensation and water accumulation on the inside of the package, which creates an atmosphere with a high level of moisture. Álvares et al. (2010) also found excessive water accumulation on the inside of the packages and attributed it to high levels of transpiration in the leaves at room temperature.

In the absence of hydrocooling, the unperforated plastic packages showed better visual conservation of the peppermint branches.

Barbosa (2015) also found darkening (chemical and/or enzymatic oxidation) of ora-pronobis leaves with or without hydrocooling and packaging after 48 hours. During the same period of time, in addition to oxidation, wilting and shriveling of the leaves were observed in the treatments without packaging.

Chlorophyll - Means testing conducted within each time point showed that at 48 hours of storage, the hydrocooled plants packaged in unperforated containers had a lower concentration of chlorophyll than the other groups. These results could be explained by the decreased water loss in this treatment, which dilutes the pigments in the leaf areas, as yellowing was observed in this treatment group 48 hours after harvest.

As a function of time, the chlorophyll level in the leaves exhibited quadratic behavior in most of the treatment groups, except in non-hydrocooled 
TABLE 2. Average values of accumulated loss of fresh mass (\%) in Mentha piperita L. leaves stored at room temperature for 48 hours, per treatment; packaging $(\mathrm{P})$, perfored packaging $(\mathrm{PP})$ and hidrocooling $(\mathrm{HC})$.

\begin{tabular}{|c|c|c|c|c|c|c|c|c|c|c|c|c|}
\hline \multirow[b]{3}{*}{$\mathbf{P}$} & \multicolumn{4}{|c|}{ Time $=0$} & \multicolumn{4}{|c|}{ Time $=6$} & \multicolumn{4}{|c|}{ Time $=12$} \\
\hline & \multicolumn{2}{|l|}{$\mathrm{HC}$} & \multicolumn{2}{|c|}{ No HC } & \multicolumn{2}{|c|}{$\mathrm{HC}$} & \multicolumn{2}{|c|}{ No HC } & \multicolumn{2}{|c|}{$\mathrm{HC}$} & \multicolumn{2}{|c|}{ No HC } \\
\hline & 0.0000 & $\mathrm{aA}$ & 0.0000 & $\mathrm{aA}$ & 1.7036 & $\mathrm{aA}$ & 1.0135 & $a A$ & 2.8961 & $\mathrm{aA}$ & 1.8626 & $\mathrm{aB}$ \\
\hline \multirow[t]{3}{*}{ PP } & 0.0000 & $\mathrm{aA}$ & 0.0000 & $\mathrm{aA}$ & 2.0722 & $\mathrm{aA}$ & 1.9639 & $\mathrm{aA}$ & 3.478 & $\mathrm{aA}$ & 3.5443 & $\mathrm{aA}$ \\
\hline & \multicolumn{4}{|c|}{ Time $=18$} & \multicolumn{4}{|c|}{ Time $=24$} & \multicolumn{4}{|c|}{ Time $=48$} \\
\hline & \multicolumn{2}{|l|}{$\mathrm{HC}$} & \multicolumn{2}{|c|}{ No $\mathrm{HC}$} & \multicolumn{2}{|c|}{$\mathrm{HC}$} & \multicolumn{2}{|c|}{ No HC } & \multicolumn{2}{|c|}{$\mathrm{HC}$} & \multicolumn{2}{|c|}{ No HC } \\
\hline $\mathbf{P}$ & 4.3098 & $\mathrm{aA}$ & 2.7286 & $b B$ & 6.8292 & $\mathrm{aA}$ & 3.309 & $\mathrm{bB}$ & 9.1588 & $\mathrm{aB}$ & 6.0715 & $b B$ \\
\hline PP & 5.1748 & $\mathrm{aA}$ & 5.3483 & $\mathrm{aA}$ & 6.1226 & $\mathrm{aA}$ & 6.4369 & $\mathrm{aA}$ & 11.7037 & $\mathrm{aA}$ & 11.3792 & $\mathrm{aA}$ \\
\hline
\end{tabular}

Means followed by the same lowercase letter in the row and the same uppercase letter in the column, for each time, do not differ according to Tukey's test at $5 \%$ probability

plants stored in perforated packages. This quadratic behavior could be explained by the presence of two phases. Initially, pigments became more concentrated as mass was lost, and the water level in the leaves decreased. However, slight yellowing, also known as loss of green color and an indicator of decreased quality, was observed in the medicinal plant as time increased. The non-hydrocooled branches stored in perforated packages only passed through the first phase, senescing before the green color loss phase.

The unpackaged plants, with or without hydrocooling, senesced very rapidly, and their chlorophyll concentrations did not change substantially during their short shelf lives.

According to Álvares et al. (2007), unperforated plastic packages may contribute to
$\mathrm{CO}_{2}$ accumulation and decreased $\mathrm{O}_{2}$ in the package interior, modifying the atmosphere and reducing the production and activity of ethylene and the enzymes responsible for degrading chlorophyll.

Accumulated loss of fresh mass - Means testing showed that non-hydrocooled plants stored in unperforated packages had less accumulated loss of fresh mass than plants stored in perforated packages after 12 hours of storage. The same was found in hydrocooled plants after 48 hours of storage (Table 2).

These results indicate better preservation of plants in unperforated packages with or without hydrocooling.

Using plastic packaging was, therefore, essential for reducing the loss of mass rate, with or without prior hydrocooling. According to Wills et

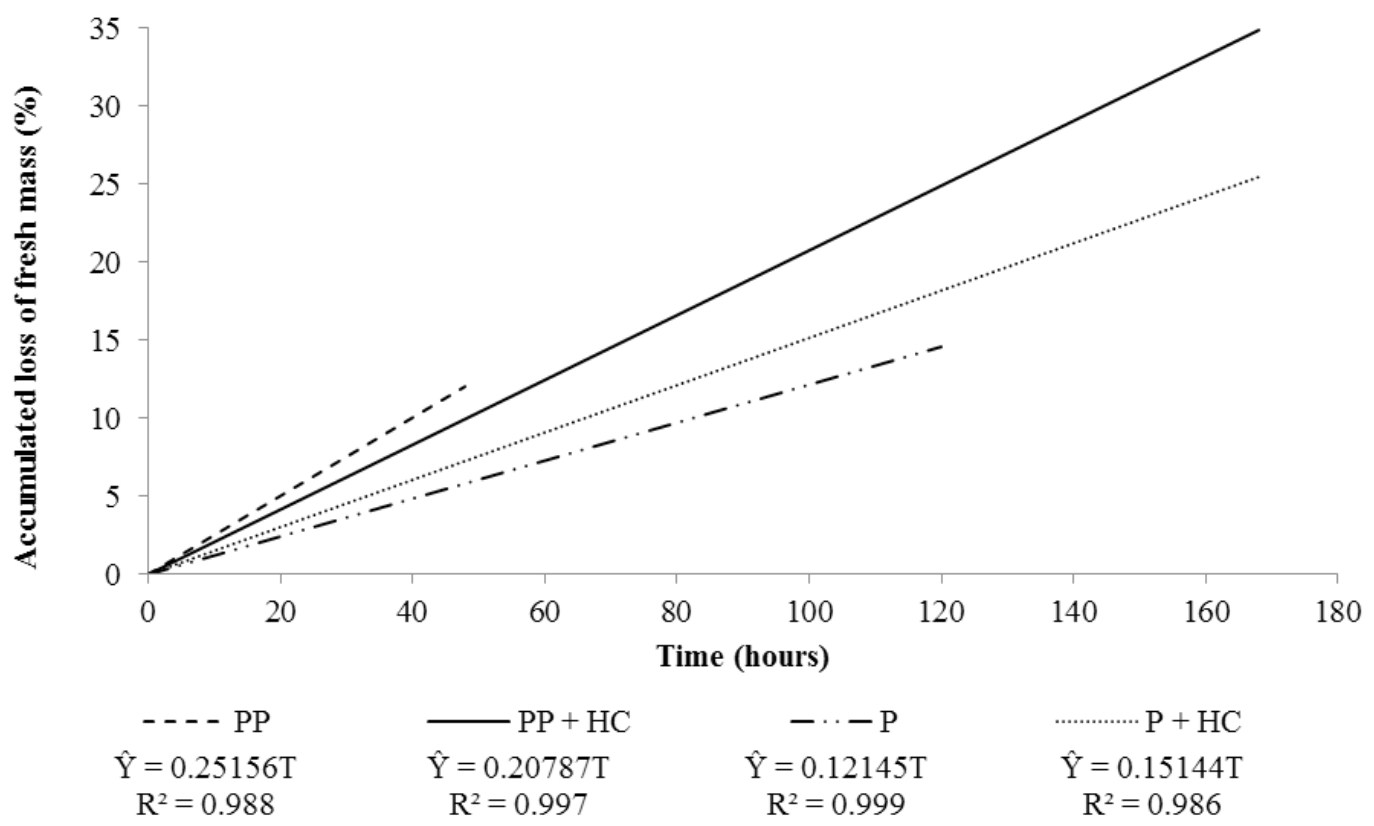

FIGURE 2. Accumulated loss of fresh mass of Mentha piperita L. leaves during storage at room temperature per treatment; packaging $(\mathrm{P})$, perfored packaging $(\mathrm{PP})$ and hidrocooling $(\mathrm{HC})$. 
al. (2007), this result was caused by an increase in and maintenance of the boundary layer, reduction in the vapor pressure deficit between the leaves and the atmosphere surrounding the product, and the creation of a modified atmosphere inside of the package, thus reducing the rate of daily fresh mass loss in the leaves.

The analysis also shows that the accumulated loss of fresh mass was higher in the hydrocooled plants after 18 hours of storage when they were packaged in unperforated packages. This high loss of mass, however, was due to loss of water adhered to or absorbed by the branches when they were hydrocooled, i.e., extra water content.

Over time, the accumulated loss of fresh mass of the leaves showed a linear and increase in all of the treatments (Figure 2).

The highest rates of fresh mass loss (percentage per hour) were found in unpackaged peppermint leaves, as the values were 2.49 in the hydrocooled and 2.33 in the non-hydrocooled branches. The higher rate for the hydrocooled branches was caused by the evaporation and percolation of the water that was adhered to the surface of the leaves or that was absorbed during the cooling process. The same phenomenon occurred during storage in unperforated packages, with a rate of 0.12 in the non-hydrocooled branches and a rate of 0.14 in the hydrocooled branches. When stored in perforated packages, the fresh mass loss rates were as high as 0.20 with hydrocooling and 0.24 without hydrocooling. Unperforated packages more effectively prevented water loss in the peppermint leaves.

The accumulated rates of loss of fresh mass in unpackaged peppermint branches, with or without hydrocooling, were $29.93 \%$ and $14.63 \%$, respectively.

Relative water content - The tests of the means showed that after 24 hours, branches without hydrocooling stored in perforated packages had lower relative water content (Table 3 ).

On average, hydrocooling increased the relative water content of the peppermint leaves by $4.30 \%$. This increase in relative water content in hydrocooled leaves was predicted by Thompson et al. (2002), due to the water absorption of slightly wilted leaves, and has been observed in multiple studies.

The relative water content of the branches decreased over time for all of the treatments used. Hydrocooled branches had a smaller decrease in the relative water content than non-hydrocooled branches. The same occurred in branches in unperforated packages compared to perforated packages. In other words, unperforated packaging helped to maintain higher levels of water in the plant tissues during storage.

In unpackaged branches, the relative water content at the end of their shelf life was $78.48 \%$ when hydrocooled and $78.80 \%$ when not hydrocooled.

Álvares et al. (2010) found a linear decrease in the relative water content of parsley branches stored at room temperature.

Carbohydrate levels - total soluble sugars - The total soluble sugar content did not change over time in any of the treatments. However, the means test showed lower levels of total soluble sugars starting at six hours of storage in hydrocooled branches packaged in perforated containers than in non-hydrocooled branches. In branches packaged in non-perforated packages, this phenomenon occurred after 12 hours of storage. This result was due to the concentration of the sugars in the branches that lost more water and, on the other side, to the dilution of sugars in more turgid branches.

Consistently, lower levels of total soluble sugars were observed in branches in unperforated packages than in branches in perforated packages at 48 hours of storage.

Reducing sugars - The levels of reducing sugars did not change as a function of time for any of the applied treatments. The means tests showed, at some time points, lower levels of reducing sugars in hydrocooled branches due to dilution, similar to the findings for total soluble sugars in this study. The test showed even lower levels of reducing sugars in leaves placed in perforated plastic packages. This reduced value can be attributed to the consumption of the sugar reserves due to higher metabolic rates in these branches than in those in packages without perforations. In other words, perforated plastic

TABLE 3. Average values of relative water content in Mentha piperita L. leaves stored at room temperature for 48 hours, per treatment; packaging $(\mathrm{P})$, perfored packaging $(\mathrm{PP})$ and hidrocooling $(\mathrm{HC})$.

\begin{tabular}{|c|c|c|c|c|c|c|c|c|c|c|c|c|}
\hline \multirow[b]{3}{*}{$\mathbf{P}$} & \multicolumn{4}{|c|}{ Time $=0$} & \multicolumn{4}{|c|}{ Time $=24$} & \multicolumn{4}{|c|}{ Time $=48$} \\
\hline & \multicolumn{2}{|c|}{$\mathrm{HC}$} & \multicolumn{2}{|c|}{$\mathrm{No} \mathrm{HC}$} & \multicolumn{2}{|c|}{$\mathrm{HC}$} & \multicolumn{2}{|c|}{ No $\mathrm{HC}$} & \multicolumn{2}{|c|}{$\mathrm{HC}$} & \multicolumn{2}{|c|}{ No HC } \\
\hline & 93.5446 & $\mathrm{aA}$ & 93.5446 & $\mathrm{aA}$ & 97.6966 & $\mathrm{aA}$ & 85.4887 & $\mathrm{aA}$ & 92.0216 & $\mathrm{aA}$ & 85.7831 & $\mathrm{aA}$ \\
\hline PP & 93.5446 & $a A$ & 93.5446 & $\mathrm{aA}$ & 97.4291 & $\mathrm{aA}$ & 82.3429 & bA & 92.1977 & $\mathrm{aA}$ & 79.1977 & $\mathrm{bA}$ \\
\hline
\end{tabular}

Means followed by the same lowercase letter in the row and the same uppercase letter in the column, for each time, do not differ according to Tukey's test at $5 \%$ probability

Rev. Bras. PI. Med., Campinas, v.18, n.1, supl. I, p.248-255, 2016. 
TABLE 4. Shelflife of Mentha piperita L. leaves in cold storage, per treatment; No packaging (NP), packaging $(P)$, perfored packaging $(P P)$ and hidrocooling $(\mathrm{HC})$.

\begin{tabular}{ccc}
\hline Treatment & $\begin{array}{c}\text { Shelflife } \\
\text { (hours) }\end{array}$ & $\begin{array}{c}\text { Shelflife } \\
\text { (relative increase }{ }^{*}\end{array}$ \\
\hline NP & 18 & \\
NP + HC & 24 & $25 \%$ \\
PP & 120 & $667 \%$ \\
PP + HC & 288 & $1500 \%$ \\
P & 192 & $967 \%$ \\
P + HC & 384 & $2033 \%$ \\
\hline * Compared to plants NP &
\end{tabular}

packages did not offer the same amount of protection as the unperforated packages. Glucose and fructose, which are reducing sugars, are direct substrates in the respiratory system and may have been consumed during leaf storage at room temperature. Non-reducing sugars - Non-reducing sugars were not detected in peppermint leaves.

Starch - Neither treatment nor time affected starch levels in peppermint leaves, indicating that starch was not used as a substrate source for leaf metabolism during storage.

\section{Experiment 2 - Postharvest quality of fresh peppermint stored under refrigeration as a function of hydrocooling and packaging}

Visual Analysis - The behavior of peppermint branches stored under refrigeration was similar to the behavior observed in Experiment I in which the plants were stored at room temperature.

The shelf life of unpackaged branches was shorter than that for packaged branches (Table 4).

However, hydrocooling lengthened the useful life (24 hours) of branches compared to those without hydrocooling (18 hours). This result was also observed in plants packaged in containers with or without perforation. The shelf life of peppermint branches packaged in perforated packages was as long as 288 hours when hydrocooled and 120 hours when not hydrocooled. Branches packaged in unperforated packages had a shelf life of 384 hours when hydrocooled and 192 hours when not hydrocooled.

The relative gain in useful life of the peppermint branches was increased 1.33 -fold (25\%) with hydrocooling, 10.67-fold with packaging alone, and 21.33-fold with hydrocooling and unperforated packaging.

Unperforated plastic packaging provided increased visual preservation of peppermint branches. In this treatment, a humid environment surrounding the product was created, as shown by the mist on the inside of the package. However, contrary to the observations in experiment I, signs of spoilage were not observed at the end of the shelf life of the hydrocooled branches. The end of their shelf life was determined solely by wilting, as in the other treatment groups.

Signs of cold injury were not observed at any time during storage, indicating that the species is tolerant of low temperatures.

Chlorophyll - As observed in Experiment $\mathrm{I}$, the means test showed that hydrocooled plants packaged in unperforated packages had a lower concentration of chlorophyll than the other groups after 48 hours of storage. This result can be explained by the lower loss of mass in this treatment and the consequent dilution of pigments in the leaf area analyzed. The same phenomenon occurred when the branches were packaged in perforated packages after 96 hours of storage.

This same result was observed in a study performed by Álvares at al. (2007) on parsley. In this study, although the chlorophyll levels did not change as a function of time, the SPAD values in hydrocooled branches were significantly lower than those in the control branches, reflecting the increased water in the tissues during the pre-cooling process, which effectively diluted the chlorophyll content.

As a function of time, the chlorophyll content of the leaves showed a positive linear response in all treatments. This response can be explained by the concentration of the pigments due to mass loss and the reduced water content in the leaves. A larger slope of the curve resulted in a larger rate of concentration, which was observed in unpackaged branches, followed by packaged and non-hydrocooled branches, and finally branches packaged after hydrocooling.

Accumulated loss of fresh mass - Unlike Experiment I, the accumulated loss of fresh mass in the peppermint leaves stored under refrigeration was not affected by the treatments. This result shows that refrigeration evens out the accumulated loss of fresh mass in the first 120 hours of storage.

However, the accumulated loss of fresh mass of the leaves as a function of time was linear and positive in all of the treatments (Figure 3 ).

The loss of mass rates (percentage per hour) observed in unpackaged peppermint leaves were larger than those in the other groups, with 1.83 for hydrocooled branches and 1.24 for the non-hydrocooled branches. When packaged in perforated packages, the rate was 0.16 in nonhydrocooled branches and 0.15 in hydrocooled branches. However, the loss of fresh mass rate was lower in the unperforated packages, with 0.13 in non-hydrocooled branches and 0.10 in hydrocooled 


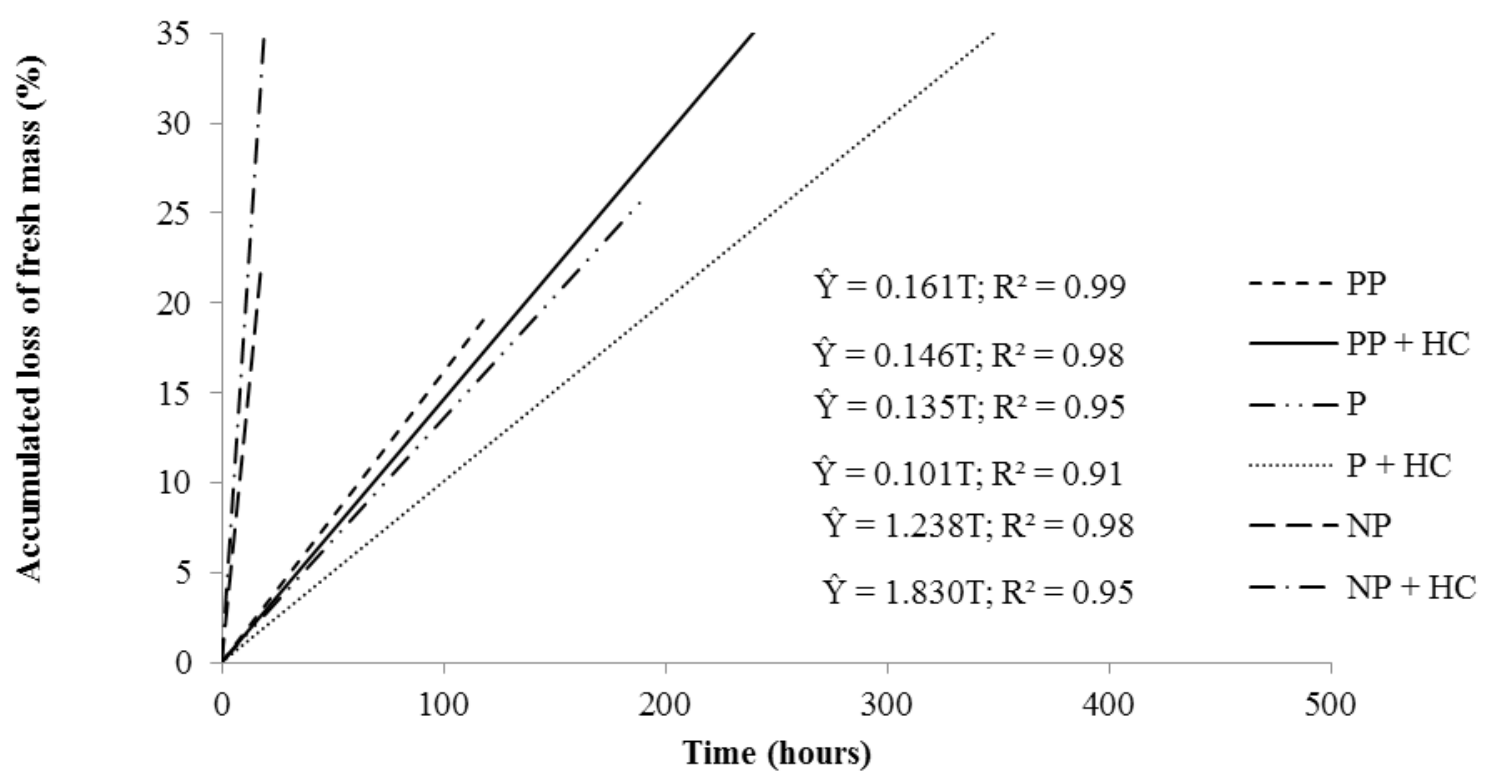

FIGURE 3. Accumulated loss of fresh mass of Mentha piperita L. leaves during cold storage, per treatment; No packaging (NP), packaging $(\mathrm{P})$, perfored packaging $(\mathrm{PP})$ and hidrocooling $(\mathrm{HC})$.

branches.

The larger rate of mass loss in nonhydrocooled branches indicates that the higher respiration rate of the plant products due to higher air temperatures during storage increased the water vapor pressure deficit in the air and, consequently, the transpiration of the leaves in air saturated with water vapor, which occurred inside unperforated PET packages containing leaves with high field heat (Ben-Yehoshua, 1987).

Gillies \& Toivonen (1995) suggested that plastic packaging, in addition to reducing the water vapor pressure deficit between the atmosphere and the product, separates the product from the refrigerated air, maintaining the temperature inside of the package below the temperature of the refrigerating room, cushioning the effects of the occasional fluctuations in the chamber temperature caused by product handling.

Álvares et al. (2010) also found a lower fresh mass loss rate in parsley branches placed in unperforated packages and a higher rate of fresh mass loss in non-hydrocooled branches.

Similar to experiment I, the unperforated package most effectively prevented water loss of peppermint leaves and produced the highest fresh mass losses in hydrocooled branches compared to non-hydrocooled branches, both without plastic packaging, indicating that water adhered or was absorbed during hydrocooling.

Relative water content - The means test showed that the unperforated package effectively

TABLE 5. Average values of relative water content in Mentha piperita L. leaves in cold storage, per treatment; packaging $(\mathrm{P})$, perfored packaging $(\mathrm{PP})$ and hidrocooling $(\mathrm{HC})$.

\begin{tabular}{|c|c|c|c|c|c|c|c|c|c|c|c|c|}
\hline \multirow[b]{3}{*}{$\mathbf{P}$} & \multicolumn{4}{|c|}{ Time $=0$} & \multicolumn{4}{|c|}{ Time $=24$} & \multicolumn{4}{|c|}{ Time $=48$} \\
\hline & \multicolumn{2}{|l|}{$\mathrm{HC}$} & \multicolumn{2}{|c|}{ No HC } & \multicolumn{2}{|l|}{$\mathrm{HC}$} & \multicolumn{2}{|c|}{ No HC } & \multicolumn{2}{|l|}{$\mathrm{HC}$} & \multicolumn{2}{|c|}{ No $\mathrm{HC}$} \\
\hline & 85.0818 & $\mathrm{aA}$ & 85.0818 & $\mathrm{aA}$ & 136.0568 & $\mathrm{aA}$ & 93.258 & $\mathrm{bA}$ & 127.7534 & $\mathrm{aA}$ & 87.226 & $\mathrm{bA}$ \\
\hline \multirow[t]{3}{*}{ PP } & 85.0818 & $\mathrm{aA}$ & 85.0818 & $\mathrm{aA}$ & 117.4970 & $\mathrm{aB}$ & 84.713 & $\mathrm{bA}$ & 112.7046 & $\mathrm{aB}$ & 79.28 & $\mathrm{bA}$ \\
\hline & \multicolumn{4}{|c|}{ Time $=72$} & \multicolumn{4}{|c|}{ Time $=96$} & \multicolumn{4}{|c|}{ Time $=120$} \\
\hline & \multicolumn{2}{|l|}{$\mathrm{HC}$} & \multicolumn{2}{|c|}{ No $\mathrm{HC}$} & $\mathrm{HC}$ & & \multicolumn{2}{|c|}{ No HC } & \multicolumn{2}{|l|}{$\mathrm{HC}$} & \multicolumn{2}{|c|}{ No HC } \\
\hline $\mathbf{P}$ & 100.4735 & $a A$ & 75.637 & $\mathrm{bA}$ & 99.5966 & $\mathrm{aA}$ & 69.46 & $\mathrm{bA}$ & 99.1167 & $\mathrm{aA}$ & 61.379 & $\mathrm{bA}$ \\
\hline PP & 101.1368 & $a A$ & 75.523 & $\mathrm{bA}$ & 95.1173 & $\mathrm{aA}$ & 68.742 & $\mathrm{bA}$ & 92.8905 & $\mathrm{aA}$ & 66.448 & $\mathrm{bA}$ \\
\hline
\end{tabular}

Means followed by the same lowercase letter in the row and the same uppercase letter in the column, for each time, do not differ according to Tukey's test at $5 \%$ probability

Rev. Bras. PI. Med., Campinas, v.18, n.1, supl. I, p.248-255, 2016. 
maintained the relative water content levels of the hydrocooled branches during the first few hours of storage. Until 48 hours of storage, the relative water content in these branches was higher than that in branches stored in perforated packages. However, after 72 hours of storage, the levels were statistically equal. The test also showed, as predicted, higher relative water content levels in hydrocooled branches than in non-hydrocooled branches throughout storage (Table 5).

The relative water content decreased linearly as a function of time in branches packaged in unperforated packages without prior hydrocooling and in hydrocooled/unpackaged branches. The relative water content did not change during storage in the other treatment groups.

This result shows lower preservation of the relative water content in unpackaged leaves and when hydrocooling is not used and packaging is conducted using perforated packages.

Carbohydrate levels - As observed in experiment I, the means tests showed that at many time points during storage, branches that were hydrocooled and/or placed in unperforated plastic packages had lower levels of total soluble, reducing, and non-reducing sugars, as well as starch.

The total soluble, reducing, and nonreducing sugar levels showed an increasing response over time in leaves with higher water content loss. However, the starch levels decreased over time in these branches. This reduction in starch levels in these treatments as a function of time indicates the chemical breakdown of starch by physiological metabolism in the leaves. Starches were most likely metabolized during the more intense respiratory processes during these treatments due to the poor preservation that these conditions provide.

\section{CONCLUSION}

The cold storage increased $64 \times(>15$ days) the shelf life of peppermint. The hydrocooling increased relative water content in leaves. Plastic packaging was effective in maintenance of relative water content. Unperforated packages more effectively prevented water loss in the peppermint leaves and prevented the leaves from wilting for a longer period of time. The leaf chlorophyll content increase or decrease acording the treatment. The soluble sugars and starch levels varied according relative water content. The hydroocoling and unperforated plastic packages was the most effective method on quality maintenance postharvest peppermint.

\section{REFERENCES}

ÁLVARES, V.S.; et al., Effect of pre-cooling on the postharvest of parsley leaves. Journal of Food, Agriculture \& Environment, v. 5, n. 2, p. 31-34, 2007.

ÁLVARES, V.S.; et al., Pré-resfriamento e embalagem na conservação de folhas de salsa. Brazilian Journal of Food Technology, v. 13, n. 2, p. 107-111, 2010.

BARBOSA, C.K.R.; FINGER, F.L. ; CASALI, V.W.D. Handling and postharvest shelf life of orapro-nobis leaves. Acta Scientiarum. Agronomy (Online), v.37, n.3, p.307-311, 2015.

BEN-YEHOSHUA, S. Transpiration, water stress and gas Exchange. In: Weichmann, J (Ed.). Postharvest physiology of vegetables. 1.ed. New York: Marcel Dekker, 1987. p.113-170.

CATSKY, J. Water content. In: SLAVIK, B. Methods of studying plants water relations.1.ed. Berlin: Springer - Verlag, 1974, p.121-131.

DOBOIS, M.; et al., Colorimetric methods of determination of sugar and related substances. Analytical Chemistry, v.28, n.3, p.350-356, 1956.

GILLIES, S.L.; TOIVONEN, P.M.A. Cooling method influences the postharvest quality of broccoli. Hortscience, v. 30, n. 2, p. 313-315, 1995.

GRANDI, T.S.M. Tratado das Plantas Medicinais: mineiras, nativas e cultivadas. 1.ed. Belo Horizonte: Adequatio Estúdio. 2014. 1204p.

MCCREADY, R.M., et al., Determination of starch and amylose in vegetables. Analytical Chemistry, n. 22, p. 1156. 1950.

NELSON, N. A photometric adaptation of Somogyi method of determination of glucose. Journal of Biological Chemistry, v.153, p.375-380,1944.

SILVA, F.; CASALI, V.W.D. Plantas medicinais e aromáticas: pós-colheita e óleos essenciais. 1.ed. Viçosa, MG. 2000. 135p.

THOMPSON, J.F.; MITCHELL, F.G.; KASMIRE, R.F. Cooling hoticultural commodities. In: KADER, A. A. Postharvest tecnology of horticultural crops. 3ed. Oakland: University of California, Division of Agriculture and Natural Resources, Publication 3311, 2002, 535p.

WEATHERLEY, P.E. Studies in the water relation of cotton plant. In: The field measurement of water deficits in leaves. New Phytologist, v.49, n.1, p.8197, 1950.

WILLS, R.; MCGLASSON, B.; GRAHAM, D.; JOYCE, $D$. Postharvest: an introduction to the physiology \& handling of fruit, vegetables \& ornamentals. 4ed. Wallingford: New South Wales University Press, 2007, 227p. 